\title{
SAFEty and efficacy of autologous bone marrow - derived mononuclear stem cell therapy in patients with severe chronic ischemic Heart Failure - rationale and design
}

\author{
MIRUNA M. MICHEU* ${ }^{*}$, NICOLETA M. POPA-FOTEA ${ }^{1}$, VLAD BATAILA ${ }^{1}$, \\ NICOLETA OPRESCU ${ }^{1}$, MARIA DOROBANTU ${ }^{1,2}$
}

${ }^{1}$ Department of Cardiology, Clinical Emergency Hospital of Bucharest, Romania

${ }^{2}$ University of Medicine and Pharmacy Carol Davila, Bucharest, Romania

\begin{abstract}
The main aim of this study is to explore the safety and efficacy of autologous bone marrow - derived mononuclear stem cell therapy in patients with severe chronic ischemic heart failure on short to medium-term (1-3 months). The SAFE-HF trial is a prospective, single center, two-arm, controlled trial with blind evaluation of endpoints. Target population will consist of patients with heart failure due to prior extensive myocardial infarction and left ventricle ejection fraction of less than $35 \%$ - namely the population with the highest risk of adverse events and the highest mortality. All patients will be treated with the state of the art reperfusion - primary percutaneous coronary intervention and also with guidelinebased optimal medical therapy. The stem cell injection will be performed 1 to 3 months after the acute event; evolution of stem cell treated patients will be compared with matched control-cases. Comprehensive assessment of outcomes will be done at 1 and 3 months follow-up; serum biomarkers, cardiac structural and physiological parameters, functional capacity and health-related quality of life will be evaluated. This pilot study possibly will serve as a foundation for designing future trials.
\end{abstract}

Keywords Stem cell therapy, myocardial infarction, heart failure, cardiac regeneration, study design.

To cite this article: MICHEU MM, POPA-FOTEA NM, BATAILA V, OPRESCU N, DOROBANTU M. SAFEty and efficacy of autologous bone marrow - derived mononuclear stem cell therapy in patients with severe chronic ischemic Heart Failure - rationale and design. Rom Biotechnol Lett. 2020; 25(6): 2118-2126. DOI: 10.25083/rbl/25.6/2118.2126

$\triangle$ *Corresponding author: MIRUNA M. MICHEU, Department of Cardiology, Clinical Emergency Hospital of Bucharest, Floreasca street, no. 8, Bucharest, Romania

E-mail: mirunamicheu@yahoo.com 


\section{Introduction}

Heart failure (HF) remains a malady with one of the highest morbi-mortality and one of the highest healthcare costs of all diseases (TOWNSEND \& al [1]). Even though myocardial infarction (MI) represents the commonest cause of HF, the best treatment and management of HF secondary to MI still remains elusive. The underlying mechanisms of development and progression of HF after MI have been comprehensively discussed starting with the 1980s (HOCHMAN \& al [2]; PFEFFER \& al [3]; PFEFFER \& al [4]; COHN \& al [5]; BURCHFIELD \& al [6]; CAHILL \& al [7]; SCHIRONE \& al [8]). The left ventricle (LV) remodeling after $\mathrm{MI}$ is a very complex process; it has an initial and active phase, from the first week to one month, after which the process slows down but still continues up to a year with additional LV ejection fraction (LVEF) worsening. Although standard-of-care drug therapy (LEVINE \& al [9]; IBANEZ \& al [10]) may delay this process, these agents do not address the fundamental issue of cell loss. One of the latest breakthroughs in the ischemic HF treatment is stem cell therapy (SCT). A growing body of evidence suggests that transplanted stem cells (SCs) secrete a variety of growth factors and cytokines, thereby enhancing myocyte survival and migration of resident cardiac SCs to the site of injury, rather than differentiating into new fully functional cardiomyocytes and blood vessels cells (KINNAIRD \& al
[11]; KINNAIRD \& al [12]). Either way, it is mandatory to target the best opportunity window for SC treatment.

\section{Materials and Methods}

\section{Study Objectives}

The main objective of SAFE-HF pilot study is to determine the safety of intracoronary injection of autologous bone marrow-derived mononuclear cells (BMMNCs) in patients with severe chronic ischemic HF following a MI on short to medium-term (1-3 months).

The secondary objectives are to investigate the efficacy of BMMNCs in improving cardiac function and clinical status in post-MI patients with ischemic LV dysfunction. In view of that, will be assessed the effect of SC therapy on short to medium-term (1-3 months) on the following parameters:

- clinical symptoms (New York Heart AssociationNYHA-Functional Classification);

- endothelial dysfunction and prothrombotic status;

- cardiac function and perfusion;

- major adverse cardiac events (MACE);

- health-related quality of life.

\section{Study Design and Population}

The SAFE-HF trial is a prospective, single-center, two-arm, controlled trial with blind evaluation of endpoints (Figure 1).

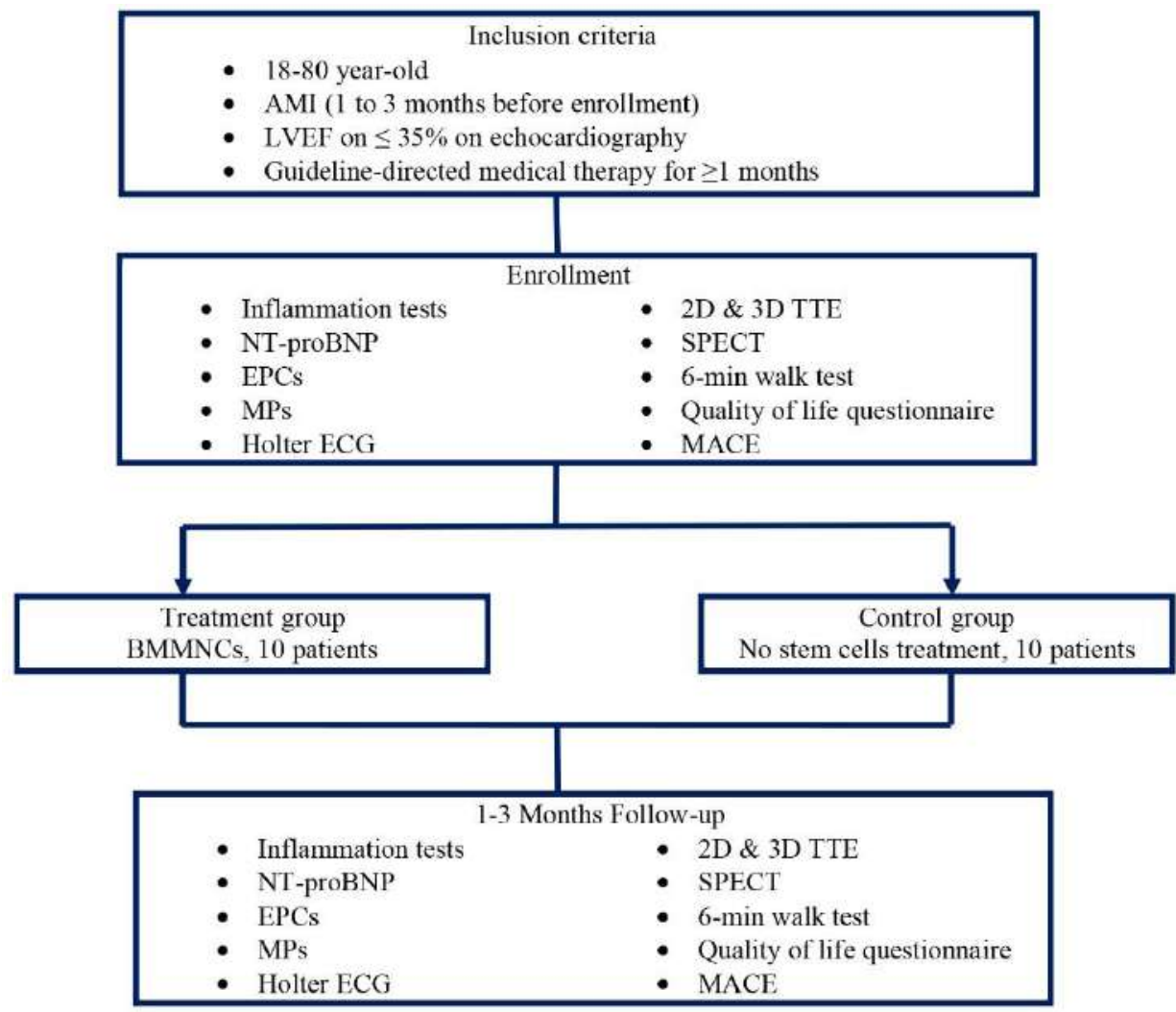

Figure 1. Clinical trial flow chart. One to 3 months from a large acute myocardial infarction (AMI), patients will receive bone marrow mononuclear stem cells (BMMNCs) or no stem cell treatment according to their assigned study group. At 1 and 3 months post-infusion, the two groups will be investigated in the same manner. LVEF - left ventricular ejection fraction, NT-proBNP - N-terminal pro brain natriuretic peptide, EPCs - circulating endothelial progenitor cells, MPs - microparticles of endothelial and platelet origin, TTE - transthoracic echocardiography, SPECT - single photon computed tomography, MACE - major adverse cardiovascular events. 
The target population consists of patients over 18 years old with a history of MI within the past 3 months and subsequent ischemic LV dysfunction (LVEF $\leq 35 \%$ ). Inclusion and exclusion criteria are detailed in Table 1 and Table 2, respectively. The study protocol was approved by the institutional ethics committee; written informed consent will be obtained from all patients before enrollment.

Twenty patients will be the total number of participants included in the trial. All of them will be treated with state of the art reperfusion - primary percutaneous coronary intervention (PCI) and also with guideline-based optimal medical therapy. Patients will be assigned to either the experimental group (undergoing autologous BMMNCs transplantation, 10 patients) or control group (10 patients). The baseline evaluation will ensure not only that the subjects fulfill the inclusion and exclusion criteria, but also will be used as a reference point to determine the impact of treatment. In this regard, patients will undergo a range of tests, comprising in-depth medical history and physical checkup, routine laboratory tests, Holter ECG monitoring, two-dimensional (2D) and three-dimensional (3D) transthoracic echocardiography (TTE) and myocardial perfusion imaging-SPECT. The level of circulating endothelial progenitor cells (EPCs) and microparticles (MPs) of endothelial and platelet origin will be assessed as surrogate markers of endothelial dysfunction and procoagulant status. Since quality of life improvement represents a central public health goal, health-related quality of life will be also analyzed in relation with SCT by using Minnesota Living with Heart Failure Questionnaire (MLHFQ). SCs will be infused intracoronary 1 to 3 months after the acute event. Neither bone marrow aspiration nor sham injection will be performed in the control group.

Table 1. Inclusion criteria
1. 18 to 80 years old (inclusive)
2. AMI (1 to 3 months before enrollment) treated with successful PCI
3. Ischemic LV dysfunction with LVEF $\leq 35 \%$ on echocardiography
4. Be treated with maximal tolerated guideline-driven medical therapy in the past month
5. Ability to provide written informed consent and follow-up with protocol procedures
AMI - acute myocardial infarction, PCI - percutaneous coronary intervention, LV - left ventricle,
LVEF - left ventricular ejection fraction

Table 2. Exclusion criteria

1. Non-ischemic cardiomyopathy
2. Ischemic cardiomyopathy beyond proposed therapeutic window ( $>3$ months AMI)
3. Active myocarditis
4. Constrictive pericarditis
5. Severe valvular disease (except severe mitral regurgitation of ischemic aetiology)
6. Hemodynamic instability
7. Major surgery or trauma $\leq 1$ month
8. Stroke $\leq 1$ month
9. Severe pulmonary disease
10. Primary haematological disease
11. Impaired renal function (serum creatinine $>2.5 \mathrm{mg} / \mathrm{dl}$ ) at the time of study inclusion
12. Liver dysfunction (AST and ALT $>3$ times the upper normal limit)
13. Hematologic abnormalities (hemoglobin $<8.5 \mathrm{mg} / \mathrm{dl}$ and/ or thrombocytes $<100.000 / \mu 1)$
14. Active infectious disease (viral or bacterial)
15. Fever $>38{ }^{\circ} \mathrm{C}$ for two consecutive days
16. Known to be positive for human immunodeficiency virus
17. History of malignancy within 5 years, without documented remission, except curatively-treated
basal cell carcinoma, squamous cell skin carcinoma, or cervical carcinoma
18. Any other severe co-morbidity associated with a reduction in life expectancy $<1$ year
19. Chronic therapy with immunosuppressant medication
20. Alcohol or drug dependence
21. Female patient of child-bearing potential and not using or not willing to use effective contraception
for the first 6 months of the study
22. Pregnancy or lactation
23. Unwilling and/or not able to give written informed consent
AMI - acute myocardial infarction, AST - aspartate aminotransferase, ALT - alanine aminotransferase

After BMMNCs injection patients will be hospitalized for at least 1 day; follow-up visits will be conducted in both groups at 4 weeks and at 3 months post-enrollment to accomplish the safety and efficacy assessments. Complete examinations will be performed at the above mentioned time points as depicted in Table 3. 


\section{Methodology of cell harvest, preparation and administration}

Fifty $\mathrm{ml}$ of bone marrow will be aspirated from the posterior iliac crest under moderate sedation and local anesthesia by a hematologist. BMMNCs will be isolated by Ficoll-Hypaque-gradient centrifugation. After being washed twice with $0.9 \% \mathrm{NaCl}$ and filtered, mononuclear cells will be resuspended in $0.9 \% \mathrm{NaCl}$ enriched with $2 \mathrm{ml}$ of autologous serum, obtaining a final volume of $12 \mathrm{ml}$ to be injected intracoronary. Subsequently, within $8 \mathrm{~h}$ after harvesting, the BMMNCs suspension will be infused in 3 series of 3 minutes into the infarct-related artery by using a stop-flow technique through an over-the-wire balloon catheter positioned within the culprit-lesion stent, as described by Strauer and collegues (STRAUER \& al [13]). The number of total nucleated cells will be measured by flow cytometry, as well as the absolute counts of CD34 ${ }^{+}$ and $\mathrm{CD} 133^{+}$progenitor cells.

\section{Endpoints}

Safety and efficacy endpoints will be evaluated at the 1-month and 3-months follow up visits as illustrated in Figure 1. The primary outcome measures for SCT safety will comprise the occurrence of any of the following: death, AMI, myocardial revascularization, hospitalization for HF decompensation, and sustained ventricular arrhythmias (ventricular arrhythmias lasting more than 30 seconds and/or with hemodynamic instability).

Secondary safety endpoints will consist of markers depicting systemic inflammation (white blood cell count, fibrinogen, erythrocyte sedimentation rate and C-reactive protein).

\section{Statistical analysis}

Considering the pilot nature of our study, the sample size was not estimated based on statistical power calculations, but was considered proper for an early-phase study.

Descriptive statistics for baseline characteristics recognized or supposed to be linked with outcomes will be completed. Data will be expressed as percentages for categorical variables and as mean \pm standard deviation for numeric variables. Continuous variables will be tested for normal distribution by Kolmogorov-Smirnov test using Lilliefors' correlation. To compare groups, we will use Student test for quantitative variables with normal distribution, respectively chi-square test for nominal or ordinal variables. All tests will be two-sided. No substitutions will be made for missing data and analyses will be based on existing data only. Statistical analysis will be performed using SPSS software version 23. Data with $p<0.05$ will be considered statistically significant.

Table 3. Events timeline in SAFE-HF study

\begin{tabular}{|c|c|c|c|}
\hline Events & Enrollment & 1 month & 3 months \\
\hline \multicolumn{4}{|l|}{ Date } \\
\hline Informed consent SAFE-HF & $\mathrm{X}$ & & \\
\hline History/physical exam & $\mathrm{X}$ & $\mathrm{X}$ & $\mathrm{X}$ \\
\hline NYHA class & $\mathrm{X}$ & $\mathrm{X}$ & $\mathrm{X}$ \\
\hline ECG & $\bar{X}$ & $\bar{X}$ & $\mathrm{X}$ \\
\hline Laboratory basic analysis & $\mathrm{X}$ & $\mathrm{X}$ & $\bar{X}$ \\
\hline Inflammation tests & $\mathrm{X}$ & $\mathrm{X}$ & $\mathrm{X}$ \\
\hline NT-pro BNP & $\mathrm{X}$ & $\mathrm{X}$ & $\mathrm{X}$ \\
\hline EPCs & $\mathrm{X}$ & $\mathrm{X}$ & $\mathrm{X}$ \\
\hline MPs & $\mathrm{X}$ & $\mathrm{X}$ & $\mathrm{X}$ \\
\hline 6-min walk test & $\mathrm{X}$ & $\mathrm{X}$ & $\mathrm{X}$ \\
\hline Holter ECG 24h & $\mathrm{X}$ & $\mathrm{X}$ & $\mathrm{X}$ \\
\hline 2D Echocardiography & $\mathrm{X}$ & $\mathrm{X}$ & $\mathrm{X}$ \\
\hline 3D Echocardiography & $\bar{X}$ & $\mathrm{X}$ & $\mathrm{X}$ \\
\hline SPECT & $\mathrm{X}$ & $\mathrm{X}$ & $\mathrm{X}$ \\
\hline Informed consent SPECT & $\mathrm{X}$ & $\mathrm{X}$ & $\bar{X}$ \\
\hline Quality of life questionnaire & $\mathrm{X}$ & $\mathrm{X}$ & $\mathrm{X}$ \\
\hline Bone marrow aspiration* & $\mathrm{X}$ & & \\
\hline SC injection* & $\mathrm{X}$ & & \\
\hline Informed consent for coronagraphy* & $\mathrm{X}$ & & \\
\hline MACE evaluation & $\mathrm{X}$ & $\mathrm{X}$ & $\mathrm{X}$ \\
\hline
\end{tabular}

*will be done only for patients in stem cells group

NT-proBNP - N-terminal pro brain natriuretic peptide; EPCs - endothelial progenitor cells; MPs - microparticles;

SPECT - Single-photon emission computed tomography; MACE - major adverse cardiac events

\section{Reporting of events}

Investigators will try to identify all adverse events through detailed anamnesis, physical examination and paraclinical investigations. Every single adverse event will be documented and promptly reported.

\section{Discussion}

The scientific accuracy of the study is guaranteed by the blind evaluation of endpoints and the presence of a matched control group. There are a number of methodologic challenges 
to be faced when designing a cardiac cell therapy study, with huge implications on the outcome. Main dares are related to selecting the patients achieving the greatest therapeutic benefit, targeting the optimal therapeutic window and choosing the appropriate endpoints (Figure 2).

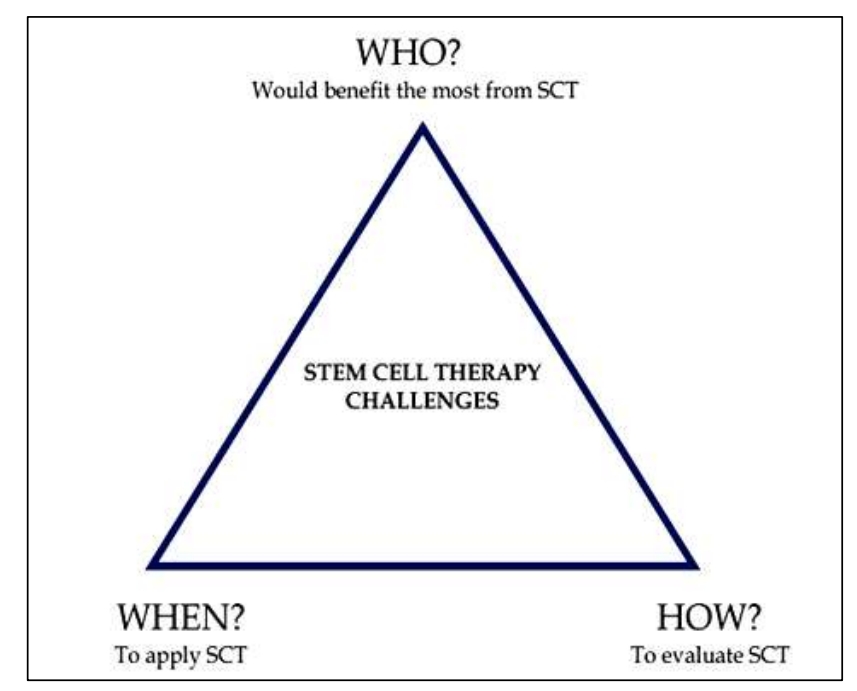

Figure 2. The main challenges of stem cell therapy. SCT - stem cell therapy.

\section{Rationale for the elected patients}

Data from subgroup analyses showed that recipients of BMMNCs transplantation with lower LVEF at baseline experienced better results as regards the increase in LVEF (BRUNSKILL \& al [14]), improvement in LV volumes (JEEVANANTHAM \& al [15]), and possibly in NYHA class at long term follow-up (FISHER \& al [16]). Moreover, recent guidelines and reviews acknowledge low LVEF as a marker of worse prognosis in patients with HF (PONIKOWSKI \& al [17]; JØRGENSEN \& al [18]). So, having in mind that patients with severely depressed systolic function $(\mathrm{LVEF}<35 \%)$ are those with the highest risk of adverse events and the highest mortality, we intend to target this exact population in our study.

\section{Rationale for the selected therapeutic window}

Cardiac remodeling after MI is a complex process involving the entire heart, regardless of necrotic, ischaemic or normally perfused areas; in addition, the occurring changes affect the myocardium as a whole, at cellular and molecular levels. Even though cardiac remodeling has an initial adaptive component which allows the heart to preserve its function as reaction to the acute injury, it is considered in general a deleterious process related to $\mathrm{HF}$ development and poor prognosis (COHN \& al [5]). The goal of existing treatments (whether pharmacological, interventional or surgical) is therefore to prevent, slow or reverse the remodeling process. SCT is a progress in this direction, addressing myocardial hypoperfusion and loss of cardiomyocytes, the fundamental aim being the prevention or limitation of adverse ventricular remodeling by inducing heart regeneration.

When choosing the time range between administration of treatment and injury, one should bear in mind the actual chronology of changes following MI. Subsequent healing is a complex, progressive process which can be divided into three stages: 1) an initial inflammatory phase characterized by increased inflammatory cells and chemical signaling with predominance of proinflammatory cytokines, resorption of necrotic tissue and recruitment of myofibroblasts, 2) a fibrotic phase characterized by myofibroblast proliferation and collagen synthesis, and 3) a long-term remodeling phase characterized by collagen matrix stabilization and maturation (JUGDUTT \& al [19]; RICHARDSON \& al [20]). As observed in previous reviews (MICHEU \& al [21]; DOROBANTU \& al [22]) and meta-analyses (LEE \& al [23]; FISHER \& al [16]; PAVO \& al [24]; PERUZZI \& al [25]; MARTIN-RENDON [26]; FISHER \& al [27]); FISHER \& al [28]), the majority of conducted trials delivered the SCs in the first days and weeks after MI- when the most active phase of LV remodeling takes place-or months, even years after MI - when the scar is already organized.

On the other hand, very few clinical trials (ANG \& al [29]; BARTUNEK \& al [30]; HELDMAN \& al [31]; MOZID \& al [32]; KIM \& al [33]) addressed the therapeutic window ranging from 1 to 3 months from the MI, a time period when the impact of intervention should not be ignored.

So, even though at first glance it would look like initial days after AMI are the optimal choice for administering SCT, there are a number of specifics which we have considered when choosing the therapeutic window: (1) the increased local inflammatory reaction through synergistic action of processes - such as reactive oxygen species production and damage-associated molecular patterns - within first week following AMI, which may hamper the survival and engraftment of transplanted SCs (ONG \& al [34]; BARTUNEK \& al [35]); (2) the spontaneous myocardial recovery occurs mostly within the first 3-4 months after AMI (POKORNEY \& al [36]); (3) the positive outcome reported when SCs were administered in a later therapeutic window sustained by completed trials such as C-CURE (BARTUNEK \& al [30]), CHART-1 (TEERLINK \& al [37]), MYSTAR (GYÖNGYÖSI \& al [38]) and CADUCEUS (MAKKAR \& al [39]); (4) the existence of the ongoing study "The effect of intracoronary reinfusion of bone marrow-derived mononuclear cells on all-cause mortality in acute myocardial infarction" - BAMI (NCT01569178). BAMI is the largest and most ambitious trial to date, aiming to determine if bone marrow-mononuclear cells are a viable option for patients with recent AMI (MATHUR \& al [40]). In the light of the aforementioned consideration, European Society of Cardiology recommended that further research trials in AMI settings should be placed on hold until the final patient outcome data from BAMI will be available (MATHUR \& al [41]).

Still, giving the multifaceted nature of the subject, selecting the optimal timing for SCT remains a challenge. Based on the above data we decided to target the timeframe of 4 weeks to 3 months since the MI, a timeframe when there is little cellular infiltration, collagen synthesis reached the plateau phase with ongoing scar formation and extracellular collagen matrix remodeling. 


\section{Rationale for the designated endpoints}

The study hypotheses ought to be converted in meaningful, well-defined endpoints that comprehend both potential benefits and risks of proposed therapy. Key areas of focus are relieving symptoms, improving health-related quality of life, reducing hospitalization and increasing survival (ALLEN \& al [42]). For an accurate assessment of therapy outcome, evaluation through several parameters from different domains is a prerequisite (DOROBANTU $\&$ al [22]). In this regard, our study complies with observations and recommendations issued by Cardiovascular Cell Therapy Research Network (CCTRN) (HARE \& al [43]).

SAFE-HF study will consider every single category of effect acknowledged by CCTRN:

- Structural evaluations: measures of LV function and perfusion;

- Cardiovascular physiological measurements: diastolic performance;

- Biomarkers: markers of systemic inflammation, NT-proBNP, EPCs, MPs;

- Functional capacity: 6-minute walk distance, NYHA classification;

- Health-related quality of life: MLHFQ.

As structural evaluations have key roles when assessing SCT benefits, we will use different imaging techniques, namely: 2D and 3D echography, as well as gated Single-Photon Emission Computed Tomography (gated-SPECT)

The echographic parameters to be measured comprise: LVEF, LV volumes, and myocardial deformation. LV volume and LVEF will be calculated with standard 2D, but also with 3D-echocardiography, the new golden-standard of cardiac echography (SPITZER \& al [44]). Considering that many studies using echographic LVEF as surrogate marker did not show significant improvement, we added recent techniques such as strain and tissue Doppler evaluations which have been proved to be more sensitive than global LVEF for the evaluation of SCT (HERBOTS \& al [45]; RUAN \& al [46]).

For the appreciation of infarct size, myocardial viability and perfusion, ECG-gated Tc-99m tetrofosmin SPECT is the technique that will be employed. The gatedSPECT images will be acquired at rest after injection of a body weight-adjusted amount of the aforesaid radiopharmaceutical. Quantitative Perfusion SPECT (QPS) and Quantitative Gated SPECT will be applied by two independent, blinded investigators. We will use the standard 17-segment model of LV in Corridor 4D-MSPECT software which will generate polar maps of the following parameters: perfusion, wall motion and wall thickening. Each LV segment will be scored on a five-point scale ( 0 , normal; 4, absent uptake) as regards the 3 mentioned parameters. Global, as well as regional perfusion, wall motion, and wall thickening will be assessed.

\section{Rationale for a prospective assessment of myo- cardial viability}

Rapid reperfusion of the infarct-related coronary artery is key determinant in rescuing ischemic myocardium and limiting the infarct size in AMI settings. So, assessment of the degree of dysfunctional but viable myocardium is an essential component of the management of patients after AMI. Viable myocardium is represented by 2 entities, both characterized by reversible contractile dysfunction: hibernating and stunned myocardium respectively. In hibernating myocardium ischaemia is still ongoing due to persistently impaired blood flow, whereas in stunned myocardium the coronary blood flow is restored (BRAUNWALD \& al [47]).

Improving functional recovery after AMI is a longstanding desideratum, since loss of viable myocardium prompts negative cardiac remodeling and additional worsening of cardiac function. One of the hypothesized mechanisms for SCs ability to regenerate the failing hearts is related to enhanced myocardial viability followed by improvement of LVEF and/or limitation of LV remodeling (RONCALLI \& al [48]).

In view of the above arguments, we consider the prospective assessment of myocardial viability a key component in evaluating SCT outcome.

\section{Possible study applications}

Stem cell therapy potential to alleviate or even cure a variety of diseases (including cardiovascular ones) represents an enormous economic opportunity. Nevertheless, the regenerative medicine market is still in its commercial formative years worldwide, and particularly in Eastern European countries where there is a stringent need of regulatory and manufacturing capabilities to create and support a feasible product portfolio and technology pipeline in this area. Depending on whether the challenges addressed by our study and other ongoing studies (NCT03227198, NCT03145402, NCT03092284) would be successfully overcome, there are chances that these contribute to the foundation of new technologies and companies.

\section{Study Strengths}

1. Comprehensive assessment of endpoints from different categories;

2. First study to exploit circulating endothelial progenitor cells and microparticles as surrogate markers of endothelial dysfunction and procoagulant status after $\mathrm{SCT}$ in $\mathrm{HF}$.

\section{Study Limitations}

First, the optimal number of BMMNCs and CD34+ progenitors to be transplanted is yet to be determined, since the existing evidence is contradictory, with some studies reporting that a lower cell dosage would be the most efficient, and others stating either an inverse or nonlinear relationship (GOLPANIAN \& al [49]). Notably, there is a significant individual variability related to the number and function of SCs with age and cardiovascular risk factors, leading to reduced effectiveness of SCT especially in patients who need it the most. Prior data from our laboratory indicate that the mean number of mononuclear cells obtained from $50 \mathrm{ml}$ of bone marrow aspirate was roughly $10^{8}$, with a mean percentage of CD34 ${ }^{+}$cells of $0.62 \pm 0.36 \%$ (MICHEU \& al [50]). In studies evaluating 
the effect of transplanted cells on myocardial function in a dose-dependent manner, this number of cells was considered high dose and also efficient (MELUZÍN \& al [51]). Similarly, a meta-analysis based on 40 randomized controlled trials and 1927 patients reported that doses between $10^{8}$ and $10^{9}$ cells were efficient in improving LVEF in AMI patients (as opposed to lower or higher dose) (XU \& al [52]).

Secondly, another possible limitation could be related to the route of administration, as injected cells can be easily washed-out. In order to overcome the poor retention of cells we will deliver the cells by a stop-flow technique using balloon occlusion followed by reperfusion. But an advantage not to forget of is that intracoronary administration enables relatively homogenous dissemination of cells in the target area.

Thirdly, due to resource and time constraints, our study will include only a limited number of patients, followed-up for 3 months. However, since long term effects of SC therapy are not well known, we intend to further follow-up the patients enrolled, pending additional funding.

\section{Acknowledgements}

This work was supported by a grant of the Romanian National Authority for Scientific Research and Innovation, CNCS/CCCDI UEFISCDI, project number PN-III-P2-2.1PED-2016-1333, within PNCDI III.

\section{References}

1. N. TOWNSEND, M. NICHOLS, P. SCARBOROUGH, M. RAYNER. Cardiovascular Disease in EuropeEpidemiological Update 2015. European Heart Journal, 36 (40): 2696-2705 (2015).

2. J.S. HOCHMAN, B.H. BULKLEY. Expansion of Acute Myocardial Infarction: An Experimental Study. Circulation, 65(7): 1446-1450 (1982).

3. J.M. PFEFFER, M.A. PFEFFER, E. BRAUNWALD. Influence of Chronic Captopril Therapy on the Infarcted Left Ventricle of the Rat. Circulation Research, 57: 84-95 (1985).

4. M.A. PFEFFER, E. BRAUNWALD. Ventricular Remodeling after Myocardial Infarction. Experimental Observations and Clinical Implications. Circulation, 81: 1161-1172 (1990).

5. J. COHN, R. FERRARI, N. SHARPE. Cardiac Remodeling - concepts and Clinical Implications: A Consensus Paper from an International Forum on Cardiac Remodeling. Journal of the American College of Cardiology, 35 (3): 569-82 (2000).

6. J.S. BURCHFIELD, M. XIE, J.A. HILL. Pathological Ventricular Remodeling: Mechanisms: Part 1 of 2. Circulation, 128 (4): 388-400 (2013).

7. T.J. CAHILL, R.K. KHARBANDA. Heart Failure after Myocardial Infarction in the Era of Primary Percutaneous Coronary Intervention: Mechanisms, Incidence and Identification of Patients at Risk. World Journal of Cardiology, 9 (5): 407-15 (2017).

8. L. SCHIRONE, M. FORTE, S. PALMERIO, D. YEE, C. NOCELLA, F. ANGELINI, F. PAGANO, S. SCHIAVON, A. BORDIN, A. CARRIZZO,
C. VECCHIONE, V. VALENTI, I. CHIMENTI, E. DE FALCO, S. SCIARRETTA, G. FRATI. A Review of the Molecular Mechanisms Underlying the Development and Progression of Cardiac Remodeling. Oxidative Medicine and Cellular Longevity, vol. 2017: 3920195 (2017).

9. N.G. LEVINE, E.R. BATES, J.C. BLANKENSHIP, S.R. BAILEY, J.A. BITTL, B. CERCEK, C.E. CHAMBERS, S.G. ELLIS, R.A. GUYTON, S.M. HOLLENBERG, U.N. KHOT, R.A. LANGE, L. MAURI, D. MEHRAN, I.D. MOUSSA, D. MUKHERJEE, H.H. TING, P.T. O'GARA, F.G. KUSHNER, R.G. BRINDIS, D.E. CASEY, M.K. CHUNG, J.A. DE LEMOS, D.B. DIERCKS, J.C. FANG, B.A. FRANKLIN, C.B. GRANGER, H.M. KRUMHOLZ, J.A. LINDERBAUM, D.A. MORROW, L.K. NEWBY, J.P. ORNATO, N. OU, M.J. RADFORD, J.E. TAMISHOLLAND, L. CARL, C.L. TOMMASO, C.M. TRACY, J. WOO, D.X. ZHAO. 2015 ACC/AHA/SCAI Focused Update on Primary Percutaneous Coronary Intervention for Patients With ST-Elevation Myocardial Infarction: A Report of the American College of Cardiology/ American Heart Association Task Force on Clinical Practice Guidelines and the Society for Cardiovascular Angiography and Interventions. Circulation, 133 (11) (2016).

10. B. IBANEZ, S. JAMES, S. AGEWALL, M.J. ANTUNES, C. BUCCIARELLI-DUCCI, H. BUENO, A. CAFORIO, F. CREA, J.A. GOUDEVENOS, S. HALVORSEN, G. HINDRICKS, A. KASTRATI, M.J. LENZEN, E. PRESCOTT, M. ROFFI, M. VALGIMIGLI, C. VARENHORST, P. VRANCKX, P. WIDIMSKÝ. 2017 ESC Guidelines for the management of acute myocardial infarction in patients presenting with ST-segment elevation: The Task Force for the management of acute myocardial infarction in patients presenting with ST-segment elevation of the European Society of Cardiology (ESC). European Heart Journal, 39 (2): 119-177 (2018).

11. T. KINNAIRD, E. STABILE, M.S. BURNETT, C.W. LEE, S. BARR, S. FUCHS, S.E. EPSTEIN. MarrowDerived Stromal Cells Express Genes Encoding a Broad Spectrum of Arteriogenic Cytokines and Promote In Vitro and In Vivo Arteriogenesis Through Paracrine Mechanisms. Circulation Research, 94 (5): 678-85 (2004).

12. T. KINNAIRD, E. STABILE, M.S. BURNETT, M. SHOU, C.W. LEE, S. BARR, S. FUCHS, S.E. EPSTEIN. Local Delivery of Marrow-Derived Stromal Cells Augments Collateral Perfusion Through Paracrine Mechanisms. Circulation, 109 (12): 1543-49 (2004).

13. B.E. STRAUER, M. BREHM, T. ZEUS, M. KÖSTERING, A. HERNANDEZ, R.V. SORG, G. KÖGLER, P. WERNET. Repair of Infarcted Myocardium by Autologous Intracoronary Mononuclear Bone Marrow Cell Transplantation in Humans. Circulation, 106 (15): 1913-8 (2002).

14. S.J. BRUNSKILL, C.J. HYDE, C.J. DOREE, S.M. WATT, E. MARTIN-RENDON. Route of Delivery and Baseline Left Ventricular Ejection Fraction, Key Factors of Bone-Marrow-Derived Cell Therapy for Ischaemic Heart Disease. European Journal of Heart Failure, 11 (9): 887-96 (2009).

15. V. JEEVANANTHAM, M. BUTLER, A. SAAD, A. ABDEL-LATIF, E.K. ZUBA-SURMA, B. DAWN. Adult Bone Marrow Cell Therapy Improves Survival and Induces Long-Term Improvement in Cardiac Parameters: 
A Systematic Review and Meta-Analysis. Circulation, 126 (5): 551-68 (2012).

16. S.A. FISHER, C. DOREE, A. MATHUR, E. MARTINRENDON. Meta-Analysis of Cell Therapy Trials for Patients With Heart Failure. Circulation Research, 116 (8): 1361-77 (2015).

17. P. PONIKOWSKI, A.A. VOORS, S.D. ANKER, H. BUENO, J. CLELAND, A. COATS, V. FALK, G.J. JOSÉ RAMÓN, V.P. HARJOLA, E.A. JANKOWSKA, M. JESSUP, C. LINDE C, P. NIHOYANNOPOULOS, J.T. PARISSIS, B. PIESKE, J.P. RILEY, G. ROSANO, L. RUILOPE, F. RUSCHITZKA, F. RUTTEN, P. VAN DER MEER. 2016 ESC Guidelines for the Diagnosis and Treatment of Acute and Chronic Heart Failure. European Heart Journal, 37 (27): 2129-2200 (2016).

18. M.E. JØRGENSEN, C. ANDERSSON, R.S. VASAN, L. KØBER, J. ABDULLA. Characteristics and Prognosis of Heart Failure with Improved Compared with Persistently Reduced Ejection Fraction: A Systematic Review and MetaAnalyses. European Journal of Preventive Cardiology, 25 (4): 366-376 (2018).

19. B.I. JUGDUTT. Ventricular Remodeling After Infarction and the Extracellular Collagen Matrix: When Is Enough Enough? Circulation, 108 (11): 1395-1403 (2003).

20. W.J. RICHARDSON, S.A. CLARKE, T.A. QUINN, J.W. HOLMES. Comprehensive Physiology, 5(4): 18771909 (2015).

21. M.M. MICHEU, M. DOROBANTU. Fifteen Years of Bone Marrow Mononuclear Cell Therapy in Acute Myocardial Infarction. World Journal of Stem Cells, 9 (4): 68 (2017).

22. M. DOROBANTU, N.M. POPA-FOTEA, M. POPA, I. RUSU, M.M. MICHEU. Pursuing Meaningful End-Points for Stem Cell Therapy Assessment in Ischemic Cardiac Disease. World Journal of Stem Cells, 9 (12): 203-18 (2017).

23. S.H. LEE, J.H. HONG, K.H. CHO, J.W. NOH, H.J. CHO Discrepancy between Short-Term and Long-Term Effects of Bone Marrow-Derived Cell Therapy in Acute Myocardial Infarction: A Systematic Review and Meta-Analysis. Stem Cell Research \& Therapy, 7 (1): 153 (2016).

24. N. PAVO, S. CHARWAT, N. NYOLCZAS, A. JAKAB, Z. MURLASITS, J. BERGLER-KLEIN, M. NIKFARDJAM, I. BENEDEK, T. BENEDEK, I.J. PAVO, B.J. GERSH, K. HUBER, G. MAURER, M. GYÖNGYÖSI. Cell Therapy for Human Ischemic Heart Diseases: Critical Review and Summary of the Clinical Experiences. Journal of Molecular and Cellular Cardiology, 75: 12-24 (2014).

25. M. PERUZZI, E. DE FALCO, A. ABBATE, G. BIONDI-ZOCCAI, I. CHIMENTI, M. LOTRIONTE, U. BENEDETTO, R. DELEWI, A. MARULLO, G. FRATI. State of the Art on the Evidence Base in Cardiac Regenerative Therapy: Overview of 41 Systematic Reviews. BioMed Research International (2015).

26. E. MARTIN-RENDON. What Can Systematic Reviews Tell Us About Cell Therapies for Ischemic Heart Disease? Circulation Research, 118 (8): 1264-1272 (2016).

27. S.A. FISHER, C. DOREE, A. MATHUR, D.P. TAGGART, E. MARTIN-RENDON. Stem cell therapy for chronic ischaemic heart disease and congestive heart failure. Cochrane Database of Systematic Reviews 2016, Issue 12. Art. No.: CD007888 (2016).

28. S.A. FISHER, C. DOREE, A. MATHUR, D. TAGGART, E. MARTIN-RENDON E. Stem Cell Therapy for Chronic
Ischaemic Heart Disease and Congestive Heart Failure. Heart, 104: 8-10 (2017).

29. K.L. ANG, D. CHIN, F. LEYVA, P. FOLEY, C. KUBAL, S. CHALIL, L. SRINIVASAN, L. BERNHARDT, S. STEVENS, L.T. SHENJE, M. GALIÑANES. Randomized, Controlled Trial of Intramuscular or Intracoronary Injection of Autologous Bone Marrow Cells into Scarred Myocardium during CABG versus CABG Alone. Nature Clinical Practice Cardiovascular Medicine, 5 (10): 663-70 (2008).

30. J. BARTUNEK, A. BEHFAR, D. DOLATABADI, M. VANDERHEYDEN, M. OSTOJIC, J. DENS, B. EL NAKADI, M. BANOVIC, B. BELESLIN, M. VROLIX, V. LEGRAND, C. VRINTS, J.L. VANOVERSCHELDE, R. CRESPO-DIAZ, C. HOMSY, M. TENDERA, S. WALDMAN, W. WIJNS, A. TERZIC. Cardiopoietic Stem Cell Therapy in Heart Failure. Journal of the American College of Cardiology, 61 (23): 2329-38 (2013).

31. A.W. HELDMAN, D.L. DIFEDE, J.E. FISHMAN, J.P. ZAMBRANO, B.H. TRACHTENBERG, V. KARANTALIS, M. MUSHTAQ, A.R. WILLIAMS, V.Y. SUNCION, I.K. MCNIECE, E. GHERSIN, V. SOTO, G. LOPERA, R. MIKI, H. WILLENS, R. HENDEL, R. MITRANI, P. PATTANY, G. FEIGENBAUM, B. OSKOUEI, J. BYRNES, M.H. LOWERY, J. SIERRA, M.V. PUJOL, C. DELGADO, P.J. GONZALEZ, J.E. RODRIGUEZ, L. BAGNO, D. ROUY, P. ALTMAN, C.W.P. FOO, J. DA SILVA, E. ANDERSON, R. SCHWARZ, A. MENDIZABAL, J.M. HARE. Transendocardial Mesenchymal Stem Cells and Mononuclear Bone Marrow Cell for Ischemic Cardiomyopathy The TACHFT Randomized Trial. JAMA, 311(1): 62-73 (2013).

32. A. MOZID, C. YEO, S. ARNOUS, E. AKO, N. SAUNDERS, D. LOCCA, P. BROOKMAN, R.A. ARCHBOLD, M. ROTHMAN, P. MILLS, S. AGRAWAL, J. MARTIN, M. ANTHONY. Safety and Feasibility of Intramyocardial versus Intracoronary Delivery of Autologous Cell Therapy in Advanced Heart Failure: The REGENERATE-IHD Pilot Study. Regenerative Medicine, 9 (3): 269-78 (2014)

33. S.H. KIM, J.H. CHO, Y.H. LEE, J.H. LEE, S.S. KIM, M.Y. KIM, M.G. LEE, W.Y. KANG, K.S. LEE, Y.K. AHN, M.H. JEONG, H.S. KIM. Improvement in Left Ventricular Function with Intracoronary Mesenchymal Stem Cell Therapy in a Patient with Anterior Wall STSegment Elevation Myocardial Infarction. Cardiovascular Drugs and Therapy, 1-10 (2018).

34. S.B. ONG, S. HERNANDEZ-RESENDIZ, G.E. CRESPOAVILAN, R.T. MUKHAMETSHINA, X.Y. KWEK, H.A. CABRERA-FUENTES, D.J. HAUSENLOY. Inflammation Following Acute Myocardial Infarction: Multiple Players, Dynamic Roles, and Novel Therapeutic Opportunities. Pharmacology \& Therapeutics, 186: 73-87 (2018).

35. J. BARTUNEK, W. William W, G.R. HEYNDRICKX, M. VANDERHEYDEN. Timing of Intracoronary Bone-Marrow-Derived Stem Cell Transplantation after ST-Elevation Myocardial Infarction. Nature Clinical Practice Cardiovascular Medicine, 3: S52-6 (2006).

36. S.D. POKORNEY, J.F. RODRIGUEZ, J.T. ORTIZ, D.C. LEE, R.O. BONOW, E. WU. Infarct Healing Is a Dynamic Process Following Acute Myocardial Infarction. Journal of Cardiovascular Magnetic Resonance, 14:62 (2012). 
37. J.R. TEERLINK, M. METRA, G.S. FILIPPATOS, B.A. DAVISON, J. BARTUNEK, A. TERZIC, B.J. GERSH, T.J. POVSIC, T.D. HENRY, B. ALEXANDRE, C. HOMSY, C. EDWARDS, A. SERON, W. WIJNS, G. COTTER. Benefit of Cardiopoietic Mesenchymal Stem Cell Therapy on Left Ventricular Remodelling: Results from the Congestive Heart Failure Cardiopoietic Regenerative Therapy (CHART-1) Study. European Journal of Heart Failure, 19 (11): 1520-1529 (2017).

38. M. GYÖNGYÖSI, I. LANG, M. DETTKE, G. BERAN, S. GRAF, H. SOCHOR, N. NYOLCZAS, N. NYOLCZAS, S. CHARWAT, R. HEMETSBERGER, G. CHRIST, I. EDES, L. BALOGH, K.T. KRAUSE, K. JAQUET, K.H. KUCK, I. BENEDEK, T. HINTEA, R. KISS, I. PRÉDA, V. KOTEVSKI, H. PEJKOV, S. ZAMINI, A. KHORSAND, G. SODECK, A. KAIDER, G. MAURER, D. GLOGAR. Combined Delivery Approach of Bone Marrow Mononuclear Stem Cells Early and Late after Myocardial Infarction: The MYSTAR Prospective, Randomized Study. Nature Clinical Practice Cardiovascular Medicine, 6(1):70-81 (2009).

39. R.R. MAKKAR, R.R. SMITH, K. CHENG, K. MALLIARAS, L. THOMSON, D. BERMAN, L. CZER, L. MARBÁN, A. MENDIZABAL, P.V. JOHNSTON, S.D. RUSSELL, K.H. SCHULERI, A.C. LARDO, G. GERSTENBLITH, E. MARBÁN. Intracoronary Cardiosphere-Derived Cells for Heart Regeneration after Myocardial Infarction (CADUCEUS): A Prospective, Randomised Phase 1 Trial. Lancet, 379 (9819): 895-904 (2012).

40. A. MATHUR, R. ARNOLD, B. ASSMUS, J. BARTUNEK, A. BELMANS, H. BÖNIG, F. CREA, S. DIMMELER, S. DOWLUT, F. FERNÁNDEZ-AVILÉS, M. GALIÑANES, D. GARCIA-DORADO, J. HARTIKAINEN, J. HILL, A. HOGARDT-NOLL, C. HOMSY, S. JANSSENS, P. KALA, J. KASTRUP, J. MARTIN, P. MENASCHE, R. MIKLIK, A. MOZID, J. SAN ROMÁN, R. SANZ-RUIZ, M. TENDERA, W. WOJAKOWSKI, S. YLÄ-HERTTUALA, A. ZEIHER. The Effect of Intracoronary Infusion of Bone Marrow-Derived Mononuclear Cells on All-Cause Mortality in Acute Myocardial Infarction: Rationale and Design of the BAMI Trial. European Journal of Heart Failure, 9(11):15451550 (2017).

41. A. MATHUR, F. FERNANDEZ-AVILES, S. DIMMELER, C. HAUSKELLER, S. JANSSENS, P. MENASCHE, W. WOJAKOWSKI, J.F. MARTIN, A. ZEIHER. The Consensus of the Task Force of the European Society of Cardiology Concerning the Clinical Investigation of the Use of Autologous Adult Stem Cells for the Treatment of Acute Myocardial Infarction and Heart Failure: Update 2016. European Heart Journal, 38 (39): 2930-35 (2017).

42. L.A. ALLEN, J.A. SPERTUS. End Points for Comparative Effectiveness Research in Heart Failure. Heart Failure Clinics, 9 (1) (2013).

43. J.M. HARE, R. BOLLI, J.P. COOKE, D. GORDON, T.D. HENRY, E.C. PERIN, K.L. MARCH, M.P. MURPHY, C.J. PEPINE, R.D. SIMARI, S.I. SKARLATOS, J.H. TRAVERSE, J.T. WILLESON, A.D. SZADY, D.A. TAYLOR, R.W. VOJVODIC, P.C. YANG, L.A. MOYÉ. Phase II Clinical Research Design in Cardiology: Learning the Right Lessons Too Well: Observations and Recommendations From the Cardiovascular Cell Therapy Research Network (CCTRN). Circulation, 127 (15): 16301635 (2013).
44. E. SPITZER, B. REN, F. ZIJLSTRA, N.M. VAN MIEGHEM, M.L. GELEIJNSE. The Role of Automated 3D Echocardiography for Left Ventricular Ejection Fraction Assessment. Cardiac Failure Review, 3 (2): 97 (2017).

45. L. HERBOTS, J. D'HOOGE, E. EROGLU, D. THIJS, J. GANAME, P. CLAUS, C. DUBOIS, K. THEUNISSEN, J. BOGAERT, J. DENS, M. KALANTZI, S. DYMARKOWSKI, B. BIJNENS, A. BELMANS, M. BOOGAERTS, G. SUTHERLAND, V. DE WERF, F.RADEMAKERS, S. JANSSENS. Improved Regional Function after Autologous Bone Marrow-Derived Stem Cell Transfer in Patients with Acute Myocardial Infarction: A Randomized, Double-Blind Strain Rate Imaging Study. European Heart Journal 30, (6): $662-70$ (2008).

46. W.RUAN, C.Z. PAN, G.Q. HUANG, Y.L. LI, J.B GE, X.H. SHU. Assessment of Left Ventricular Segmental Function after Autologous Bone Marrow Stem Cells Transplantation in Patients with Acute Myocardial Infarction by Tissue Tracking and Strain Imaging. Chinese Medical Journal, 118 (14): 1175-81 (2005).

47. E. BRAUNWALD, R.A. KLONER. The Stunned Myocardium: Prolonged, Postischemic Ventricular Dysfunction. Circulation, 66 (6): 1146-49 (1982).

48. J. RONCALLI, F. MOUQUET, C. PIOT, J.N. TROCHU, P. LE CORVOISIER, Y. NEUDER, T. LE TOURNEAU, D. AGOSTINI, V. GAXOTTE, C. SPORTOUCH, M. GALINIER, D. CROCHET, E. TEIGER, M.J. RICHARD, A.S. POLGE, J.P. BEREGI, A. MANRIQUE, D. CARRIE, S. SUSEN, B. KLEIN, A. PARINI, G. LAMIRAULT, P. CROISILLE, H. ROUARD, P. BOURIN, J.M. NGUYEN, B. DELASALLE, G. VANZETTO, E. VAN BELLE, P. LEMARCHAND. Intracoronary Autologous Mononucleated Bone Marrow Cell Infusion for Acute Myocardial Infarction: Results of the Randomized Multicenter BONAMI Trial. European Heart Journal, 32 (14): 1748-57 (2011).

49. S. GOLPANIAN, I.H. SCHULMAN, R.F. EBERT, A.W. HELDMAN, D.L. DIFEDE, P.C. YANG, C.J. WU, R. BOLLI, E.C. PERIN, L. MOYÉ, R.D. SIMARI, A. WOLF, H.M. HARE. Concise Review: Review and Perspective of Cell Dosage and Routes of Administration From Preclinical and Clinical Studies of Stem Cell Therapy for Heart Disease. STEM CELLS Translational Medicine, 5(2): 186-91 (2016).

50. M.M. MICHEU, N. OPRESCU, A.I. SCARLATESCU, L. CALMAC, D. PITIC, M. DOROBANTU. TRANSTEM Pilot Study - Design, Safety and Results 6 Months after Autologous Bone Marrow Stem Cell Transplant in Patients with Acute Myocardial Infarction and Impaired Left Ventricular Function. Journal of Translational Medicine and Research, 20 (4): 215 (2015).

51. J. MELUZIN, J.MAYER, L. GROCH, S. JANOUSEK, I. HORNACEK, O. HLINOMAZ, P. KALA, R. PANOVSKÝ, J. PRASEK, M. KAMINEK, J. STANICEK, M. KLABUSAY, Z. KORISTEK, M. NAVRATIL, L. DUSEK, J. VINKLARKOVA. Autologous Transplantation of Mononuclear Bone Marrow Cells in Patients with Acute Myocardial Infarction: The Effect of the Dose of Transplanted Cells on Myocardial Function. American Heart Journal, 152 (5): 975.e9-975.e15 (2006).

52. J.Y. XU, W.Y. CAI, M. TIAN, D. LIU, R.C. HUANG. Stem Cell Transplantation Dose in Patients with Acute Myocardial Infarction: A Meta-Analysis. Chronic Diseases and Translational Medicine 2 (2): 92-101 (2016). 